\title{
Germination of Miconia ligustroides (Melastomataceae) diaspores submitted to different treatments for dormancy overcoming
}

\author{
IZABEL DE SOUZA CHAVES ${ }^{1,3}$, AMAURI ALVES DE ALVARENGA², SARA DOUSSEAU ${ }^{2}$, \\ GIULIANA CRISTINA MOURÃO SOARES ${ }^{1}$, ELMA DOS SANTOS SOUZA ${ }^{1}$ and \\ MARIANA ALINE SILVA ARTUR ${ }^{2}$
}

(received: March 1, 2011; accepted June 10, 2011)

\begin{abstract}
Germination of Miconia ligustroides (Melastomataceae) diaspores submitted to different treatments for dormancy overcoming). To assess the germination behavior of Miconia ligustroides (DC.) Naudin, diaspores were submitted to different regimes of temperature, light and substrate. Due to intrinsic low germination of the diaspores, they were submitted to treatments that aimed to overcome endogenous and exogenous dormancy. Miconia ligustroides presents complex dormancy and to overcome it is recommended to soak the diaspores in $\mathrm{H}_{2} \mathrm{SO}_{4}$ diluted at $75 \%$ for 5 minutes, wash it and then soak it in a solution of $400 \mathrm{mg} \mathrm{L}^{-1}$ of $\mathrm{GA}_{3}$ for 12 hours. Seeding should be done on Germtest ${ }^{\circledR}$ paper at $25^{\circ} \mathrm{C}$.
\end{abstract}

Key words - complex dormancy, germinability, jacatirão-do-brejo

RESUMO - (Germinação de diásporos de Miconia ligustroides (Melastomataceae) submetidos a diferentes tratamentos de superação de dormência). Para avaliar o comportamento germinativo de Miconia ligustroides (DC.) Naudin, diásporos foram submetidos a diferentes regimes de temperatura, luz e substrato. Devido à baixa germinabilidade dos diásporos, foram realizados tratamentos de superação de dormência endógena e exógena. Miconia ligustroides apresenta dormência complexa e para superá-la recomenda-se a imersão dos diásporos em $\mathrm{H}_{2} \mathrm{SO}_{4}$ diluído a $75 \%$ por 5 minutos, seguida de lavagem e embebição em solução de $400 \mathrm{mg} \mathrm{L}^{-1}$ de $\mathrm{GA}_{3}$ por 12 horas. A semeadura deve ser realizada em papel Germtest ${ }^{\circledR}$ à $25^{\circ} \mathrm{C}$.

Palavras-chave - dormência complexa, germinabilidade, jacatirão-do-brejo

\section{Introduction}

Ensuring the survival of plant species is directly linked to the existence of seeds, which symbolize its continuity and diversity. However, besides containing the genetics traits of the parents, the seeds are capable of receiving stimuli from the environment during or after their formation, allowing them to change their behavior after their release from the mother plant. So, after adapting to the environment, many plants species started to develop, in evolutionary terms, mechanisms that allow their survival. Among these, seed dormancy represents one of the key skills of plant species to ensure their survival and perpetuation, being related to the life cycle and hardiness of the species (McIvor \& Howden 2000).

Dormancy is a phenomenon in which the seeds of some species, even though viable and possessing all the environmental conditions to start the germination process, do not germinate (Bewley \& Black 1994). Based on the putative mechanisms involved, dormancy can be classified

1. Universidade Federal de Viçosa, Departmento de Biologia, Campus Universitário, 36570-000 Viçosa MG, Brazil.

2. Universidade Federal de Lavras, Departmento de Biologia, Campus Universitário, Caixa Postal 3037, 37200-000 Lavras, MG, Brazil.

3. Correspondenting author: izabelchaves@yahoo.com.br into two major groups: endogenous and exogenous (Cardoso 2004). Endogenous dormancy is caused by some germination blockage related to the embryo itself, but eventually may involve extra-embryonic tissues, and can be divided into: physiological, morphological, and morphophysiological. Morphological dormancy occurs in seeds that are shed from the parent plant when their embryos are not fully developed, since they are rudimentary or torpedo-shaped (Arteca 1996).

Exogenous or extra-embryonic dormancy is caused primarily by the integument, the endocarp, the pericarp and/or by extrafloral organs, and usually by little or no direct participation of the embryo in its overcoming. In general, the mechanisms responsible for this type of dormancy are related to impermeability, mechanical effect, and/or to presence of inhibitory substances in the tissues. They can be divided into physical, chemical and mechanical (Cardoso 2004). Importantly, the same species may show different degrees and types of dormancy. For species that present more than one type of dormancy, the dormancy is often said to be complex or combined.

According to Zaidan \& Barbedo (2004), the importance of different degrees of dormancy is to prevent a rapid and uniform germination of all seeds produced in a given time, which may result in competition among 
seedlings or in the death of all of them immediately after its emergence, in case of occurrence of a drastic change in the environmental conditions. Still, dormancy is often a detrimental issue to the activities of a nursery, where large quantities of seeds are expected to germinate in a short time, allowing the production of uniform seedlings. In addition, the seed lots that have some type of dormancy may have its viability underestimated, when low values of germination percentage are obtained. In this case, knowledge of the dormancy causes is of significant practical importance, allowing the application of an appropriate treatment to ensure a better germination (Melo et al. 1998).

Miconia ligustroides (DC.) Naudin (Melastomataceae), popularly known as jacatirão-dobrejo, is widely distributed in Brazil, occurring from Ceará to Santa Catarina (Martins et al. 1996). Generally it occupies savannahs, fields, swamps and wet locations (Goldenberg 2004). It can be characterized as a bush or a 0.5 to $4.5 \mathrm{~m}$ tree. Its fruits are dispersed by animals, being a major attraction for wildlife. Often, it also has a large number of bromeliads attached to its stems (Bonnet $\&$ De Queiroz 2006). Miconia ligustroides has analgesic (Cunha et al. 2003) and trypanocidal (Cunha et al. 2006) qualities. Although the species present medical and ecological importance, there are only a few studies concerning its sexual propagation, which justify the development of an efficient technology that facilitate its management in large scale, especially in regard to dormancy overcoming.

\section{Material and methods}

To assess the influence of light and temperature on germination, the diaspores were sown on two sheets of Germtest ${ }^{\circledR}$ paper moistened with distilled water (2.5 fold the weight of the paper) and placed in Petri dishes (Brasil 2009). Later they were placed in BOD incubator at constant temperatures of $20^{\circ} \mathrm{C}, 25^{\circ} \mathrm{C}, 30^{\circ} \mathrm{C}$ and $35^{\circ} \mathrm{C}$ and $20-30{ }^{\circ} \mathrm{C}$, with relative humidity around $60 \% \pm 3 \%$, at photoperiod of 12 hours. To simulate the dark conditions, the Petri dishes were wrapped with two sheets of aluminum foil and then covered with polystyrene bags, in order to guarantee dark condition. Germination behavior was evaluated under green safe light (Santos et al. 2005).

The influence of substrate on germination was tested by sowing on two sheets of Germtest ${ }^{\circledR}$ paper, on sand, in a vermiculite or on Plantmax ${ }^{\circledR}$, kept in a BOD incubator regulated to maintain the temperature at $25^{\circ} \mathrm{C}, 12$ hours photoperiod and $60 \% \pm 3 \%$ relative humidity. The experiments were conducted in a complete randomized design (CRD) with four replicates of 50 diaspores each. Germination evaluations were performed daily, and using as a parameter the protrusion of $\geq 1 \mathrm{~mm}$ of radicle for the diaspores sown on paper and the emergence of the hipocotyledonar hook for the diaspores sown on other substrates. We calculated the total percentage of germination and germination speed index (GSI) according to Maguire (1962). Statistical analysis was performed by means of an analysis of variance. Means were further compared by the Tukey test $(P \leq 0.05)$. For these analyses we used the statistical program Sisvar (Ferreira 1999).

To evaluate the presence of endogenous dormancy in the diaspores they were submitted to the following treatments that aimed to overcome dormancy: immersion and agitation for 12 hours in gibberellic acid $\left(\mathrm{GA}_{3}\right)$ solution at concentrations of 200, 400, 600 and $800 \mathrm{mg} \mathrm{L}^{-1}$, in potassium nitrate $\left(\mathrm{KNO}_{3}\right)$ solution at concentrations of $1 \mathrm{~m}$ and $0.2 \mathrm{M}$, and the combination of these two substances at concentration of $800 \mathrm{mg} \mathrm{L}^{-1}$ of $\mathrm{GA}_{3}$ and $0.1 \mathrm{~m} \mathrm{KNO}_{3}$. As a control, diaspores were immersed and agitated in water, for 12 hours. Later, the diaspores were placed to germinate on Petri dishes covered with Germtest ${ }^{\mathbb{B}}$ paper in BOD incubator at $25^{\circ} \mathrm{C}$, with 12 hours photoperiod and $60 \% \pm 3 \% \mathrm{RH}$. Diaspore germination was evaluated daily with the aid of a magnifying glass. The experiment was conducted in a complete randomized design (CRD) with four replicates of 50 diaspores each. Statistical analysis was performed by means of an analysis of variance. Means were further compared by the Scott-Knott test $(P \leq 0.05)$ using the software Sisvar.

The seeds were analyzed by scanning electron microscopy (SEM) to evaluate the presence of morphological dormancy, according to the protocol established by Alves (2004). This protocol suggests that once fixated, the diaspores should be frozen in liquid nitrogen and sectioned longitudinally to observe the internal structures. The samples were analyzed by scanning electron microscope (LEO EVO 40 XVP Cambridge, United Kingdom).

The presence of physical or mechanical dormancy was analyzed by subjecting the diaspores to treatments with sulfuric acid $\left(\mathrm{H}_{2} \mathrm{SO}_{4}\right)$ and thermal shock. Diaspores were treated with $\mathrm{H}_{2} \mathrm{SO}_{4} 75 \%$ for 5,10 and 15 minutes and concentrated $\mathrm{H}_{2} \mathrm{SO}_{4}$ for 30 and 60 seconds, then thoroughly washed in running water. For the heat shock test, diaspores were quickly dipped in hot water and then in cold water. The diaspores were placed to germinate under the same conditions of treatments for dormancy overcoming previously described, and assessed in the same way.

The assessment of combined dormancy was performed by combining the best results of the previous treatments (400 mg L-1 of $\mathrm{GA}_{3}$ plus $\mathrm{H}_{2} \mathrm{SO}_{4} 75 \%$ for 5 minutes). The germination test was performed in the same conditions as previously described, and assessed in the same way.

\section{Results and discussion}

Regardless of the temperature tested, there was no germination in darkness, therefore $M$. ligustroides 
can be considered essentially as photoblastic positive. According to Carreira \& Zaidan (2007), other species of Miconia (M. albicans (Sw.) Triana, M. langsdorffii Cong., M. rubiginosa (Bonpl.) DC. and M. stenostachya Schr. \& Mart. ex DC.) present the same characteristic. Godoi \& Takaki (2007), studying M. theaezans found that its seeds have strong dependence on the presence of white light to induce germination with daily need of 4-6 hours of light for maximum induction of the process.

The germination of $M$. ligustroides was higher at $25^{\circ} \mathrm{C}$ and lower at $20-30{ }^{\circ} \mathrm{C}$, and no germination at all occurred at $35^{\circ} \mathrm{C}$. However, there was no significant difference in germination when the diaspores were subjected to constant temperatures of $20^{\circ} \mathrm{C}$ and $30{ }^{\circ} \mathrm{C}$ (figure 1). The GSI followed the same pattern found in the germination. All protruded seeds gave rise to normal seedlings.

According to Bewley \& Black (1994), temperature influences the speed and the final percentage of germination, affecting both water absorption by the seeds and the biochemical reactions that regulate the metabolism involved in this process. Seeds are able to germinate under a wide range of temperatures, being set for each species a minimum and a maximum temperature, above and below which germination does not occur (Bewley \& Black 1994). Such behavior indicates the adaptive potential of $M$. ligustroides, since it demonstrates an ability to establish greater than that found when there is thermal restriction (Thompson, 1970, Townsend \& McGinnies 1972). In this context, the diaspores of M. ligustroide subjected to thermal regimes of $20^{\circ} \mathrm{C}$ and $30{ }^{\circ} \mathrm{C}$ had lower $\% \mathrm{G}$ and GSI when compared to $25^{\circ} \mathrm{C}$, probably because the variation in temperature slowed the process,

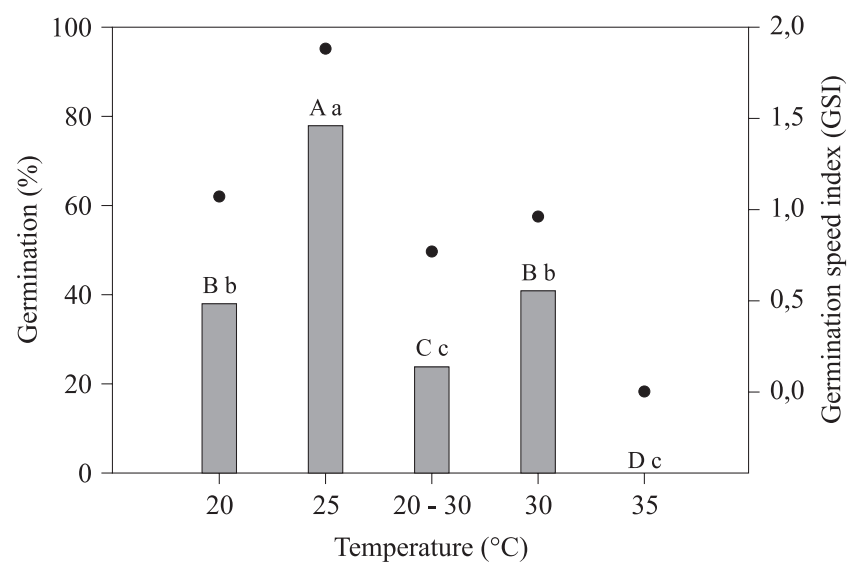

Figure 1. Germination behaviour of Miconia ligustroides diaspores subjected to different temperatures. Upper case letters compare $\%$ germination (bars) and lower case compare GSI (dot). due to the reduction on the activity of enzymes involved in the metabolism of the seed (Simon et al. 1976, Bewley $\&$ Black 1994). The increase in temperature to $35^{\circ} \mathrm{C}$, on the other hand is probably beyond the maximum temperature for germination. Alternating temperatures (20-30 ${ }^{\circ} \mathrm{C}$ ) decreased the $\% \mathrm{G}$ and GSI when compared to $25^{\circ} \mathrm{C}$. Mayer \& Poljakoff-Mayber (1989) reported that alternating temperatures may be more effective in promoting germination than each temperature applied alone, a fact that has not been demonstrated in seeds of $M$. ligustroides, neither in seeds of species studied by Carreira \& Zaidan (2007) nor in seeds of M. chamissois Naudin (Válio \& Scarpa 2001).

Temperature alters the embryo growth potential and influences hormonal levels. At higher temperatures termoinhibition may occur due to induction of abscisic acid (ABA) synthesis (Leymarie et al. 2008; Toh et al. 2008) and giberellin (GA) repression (Toh et al. 2008).

Diaspores germinated on paper showed higher $\% \mathrm{G}$ and GSI (figure 2). The results in other substrates did not differ. The substrate used in the germination tests has a great influence on the germination, since factors such as structure, aeration, water retention capacity, pathogen infestation may vary depending on the type of material used (Popinigis 1977). The choice must be made according to the requirements of the seed, regarding its size and shape (Brasil 2009). Vermiculite and Plantmax ${ }^{\circledR}$ have a good capacity to absorb and hold water, while sand is difficult for maintaining moisture, because it is uneven in terms of water retention and distribution. Thus, seeds of $M$. ligustroides prefer substrates with lower water retention, such as paper (preferably) and sand.

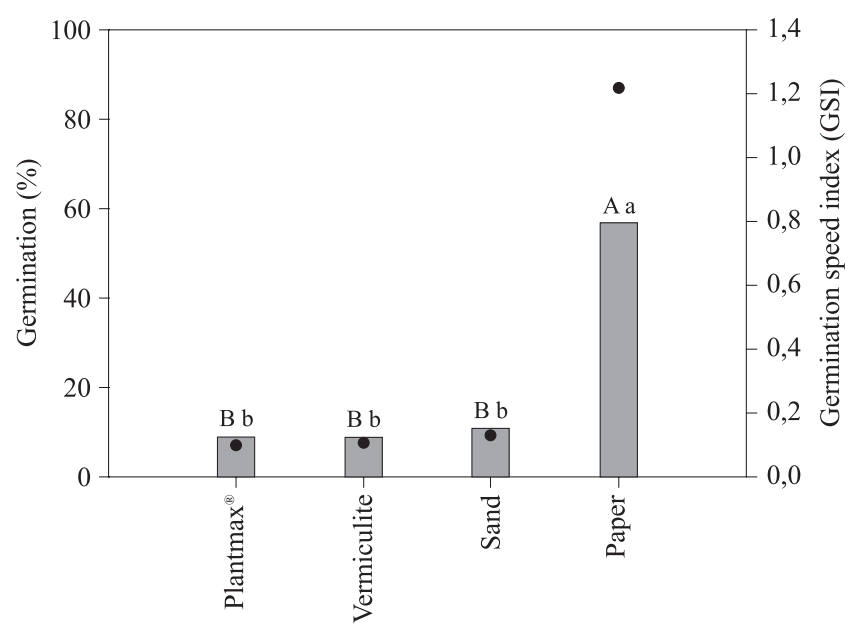

Figure 2. Germination behaviour of Miconia ligustroides diaspores subjected to different substrates. Upper case letters compare \% germination (bars) and lower case compare GSI (dot). 
According to the literature, Melastomataceae species occurring in the Atlantic Forest germinate around 30\% (Amaral \& Paulilo 1992, Zaia \& Takaki 1998, Carreira \& Zaidan 2007). In M. ligustroides the germination percentage was $55 \%$, a relatively low value.

Regarding the treatments used to overcome physiological dormancy, higher results of $\% \mathrm{G}$ were obtained with solutions of $400 \mathrm{mg} \mathrm{L}^{-1} \mathrm{GA}_{3}(96 \%)$, followed by immersion in 0.1 and $0.2 \mathrm{M} \mathrm{KNO}_{3}$ solutions (figure 3). These were followed by the treatments with $\mathrm{GA}_{3}$ at $200 \mathrm{mg} \mathrm{L}^{-1}$, and $800 \mathrm{mg} \mathrm{L}^{-1}$ plus $0.2 \mathrm{M} \mathrm{KNO}_{3}$ and immersion and agitation in water for 12 hours, which did not differ among them. Soaking in $\mathrm{GA}_{3}$ at $800 \mathrm{mg} \mathrm{L}^{-1}$ and the control treatment provided the lowest values. The same pattern was observed in the GSI, which is an indicative of physiological quality and germination uniformity of the seeds. GSI increased with treatments for dormancy overcoming in relation to the control, but the values remained very low. This justifies the development of studies that aim to increase GSI, as will be described later in the works about acid scarification.

The morphophysiological dormancy was characterized by the presence of immature embryos, all in the globular stage of development, observed by SEM (figure 4-7). The embryo of $M$. ligustroides is constituted, at the moment of dispersal, of a

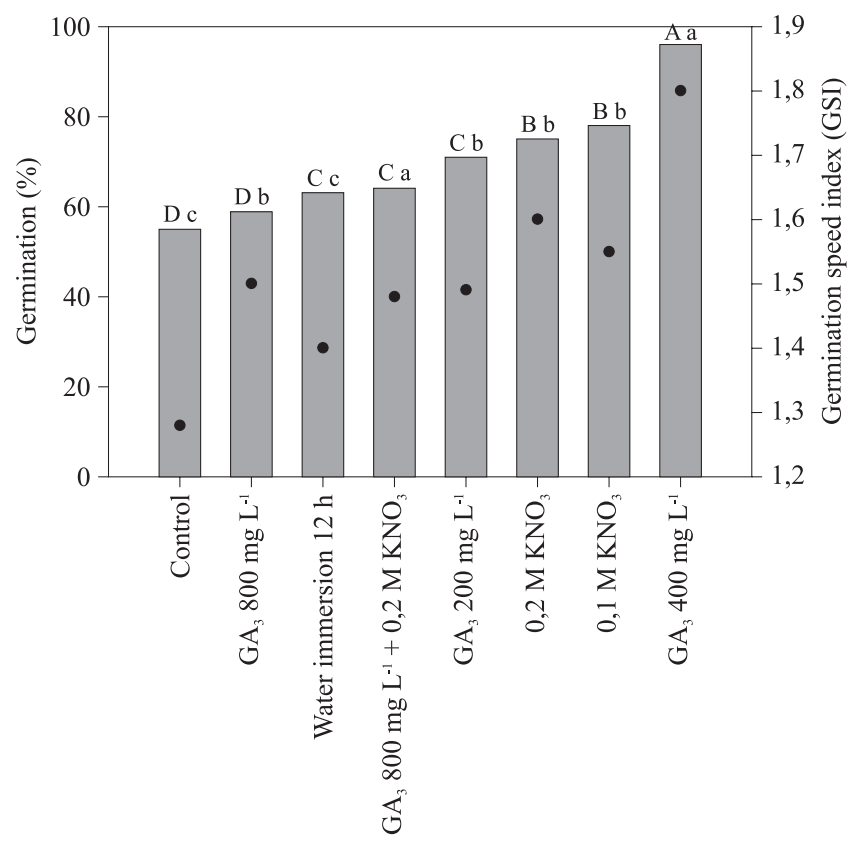

Figure 3. Germination behaviour of Miconia ligustroides diaspores subjected to different treatements aiming endogenous dormancy overcoming. Upper case letters compare \% germination (bars) and lower case compare GSI (dot). mass of hyaline cells, in which it is not possible to identify the cotyledons or the axis, even under high resolution (figure 5). The immaturity of embryo delays germination until the complete development of the embryo.

Regarding the GSI, the best treatment to overcome dormancy was immersion in $\mathrm{H}_{2} \mathrm{SO}_{4} 75 \%$ for 5 minutes (figure 8). However, the results of immersion in $\mathrm{H}_{2} \mathrm{SO}_{4}$ $75 \%$ for 10 minutes and immersion in $\mathrm{H}_{2} \mathrm{SO}_{4} 75 \%$ for 15 minutes did not differ between them. The control and heat shock treatment did not differ between them also, they being, however, lower than the treatments mentioned above. The immersion in $\mathrm{H}_{2} \mathrm{SO}_{4}$ for 30 and 60 seconds had the worst results. Acid scarification promoted an increase of GSI, resulting in the synchronization of germination. This is an especially important factor for the production of seedlings in nurseries, which demands a rapid germination.

Importantly, the germinability of the diaspores submitted to these treatments was lower than that found in the treatment of endogenous dormancy (lower than $60 \%$ ). However, the GSI of the diaspores soaked in $\mathrm{H}_{2} \mathrm{SO}_{4}$ diluted to $75 \%$ for 5 minutes was higher than all other treatments, demonstrating that, besides the presence of morphophysiological dormancy, seeds of M. ligustroides also possess a type of physical dormancy, therefore characterizing a complex dormancy. For treatments tested to overcome endogenous dormancy it was also observed a higher timing of germination compared to control.

The presence of physical dormancy is probably due to the presence of the thick integument of $M$. ligustroides diaspores, as observed by SEM (figures 4, 7). The thick outer mantle hinders absorption of water and oxygen by the seeds, retarding germination. The acid treatment, probably promoted the partial degradation of the outer envelope allowing a faster imbibition and thus an early root protrusion. On the other hand, the lower $\% \mathrm{G}$ may has been due to the fact that only embryos at later stages of development have sprouted. Although we couldn't find any study that aimed the dormancy overcoming in species of Miconia, several studies reporting success in overcoming this kind of dormancy can be found, especially using immersion in $\mathrm{H}_{2} \mathrm{SO}_{4}$, (Alves 2000, Albuquerque et al. 2007, Azania et al. 2009, Benedito et al. 2009).

The combination of the treatments for endogenous and exogenous dormancy overcoming promoted high values of $\% \mathrm{G}(98 \%)$ and GSI (3.00). The partial degradation of the outer mantle, probably allowed a faster imbibition of $\mathrm{GA}_{3}$. 

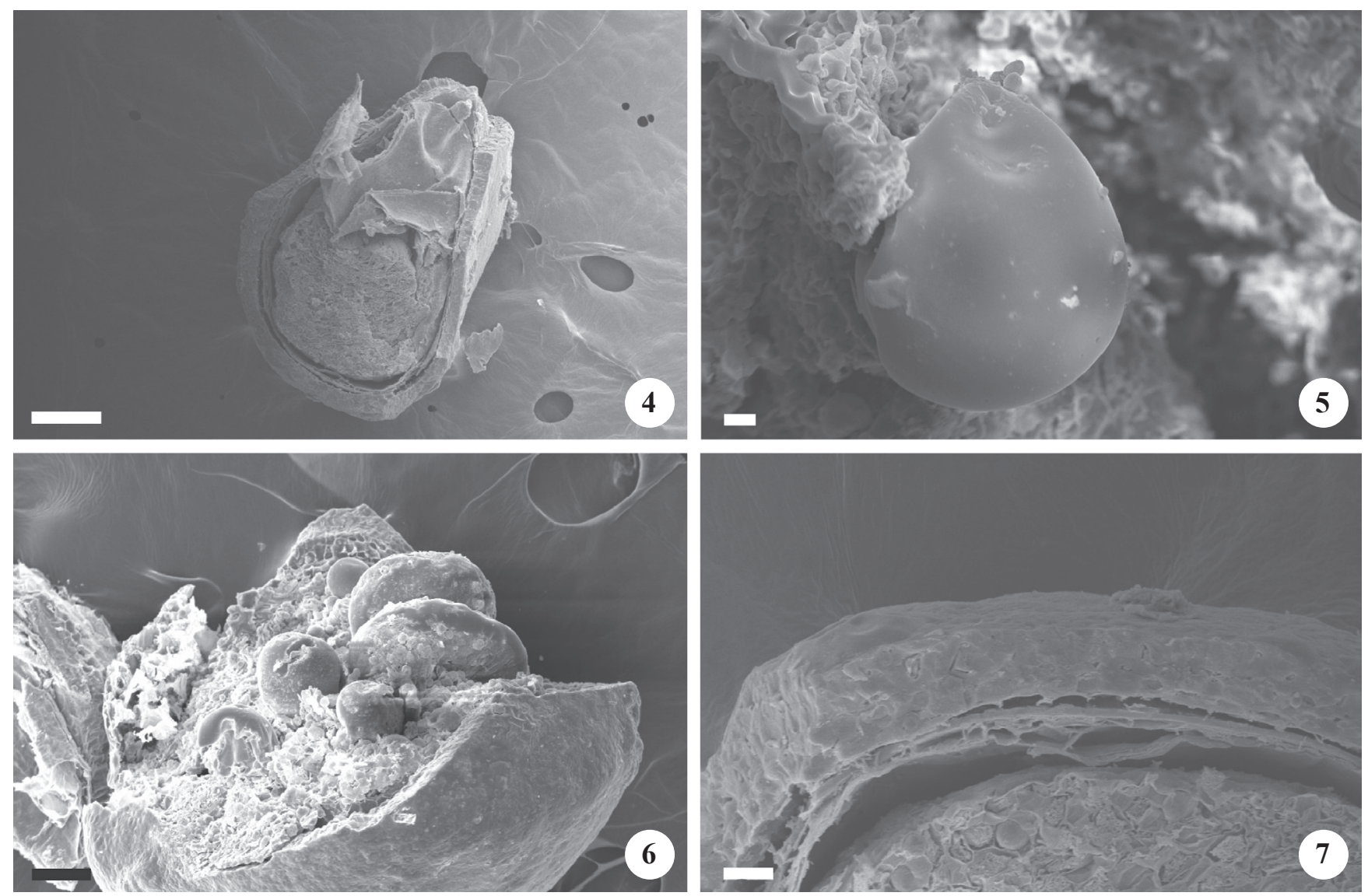

Figures 4-7. Electron-micrographs of Miconia ligustroides seeds. 4. Aspect of the seed, with thick integuments and embryo cell mass. 5. Embryo at the globular stage of development. 6. Polyembryony evidenced by the presence of six embryos in the globular stage of development. 7. Thick integument of the seeds, which are characteristic of species that possess exogenous dormancy. Bar $=200 \mu \mathrm{m}(4,5) ; 100 \mu \mathrm{m}(6) ; 300 \mu \mathrm{m}(7)$.

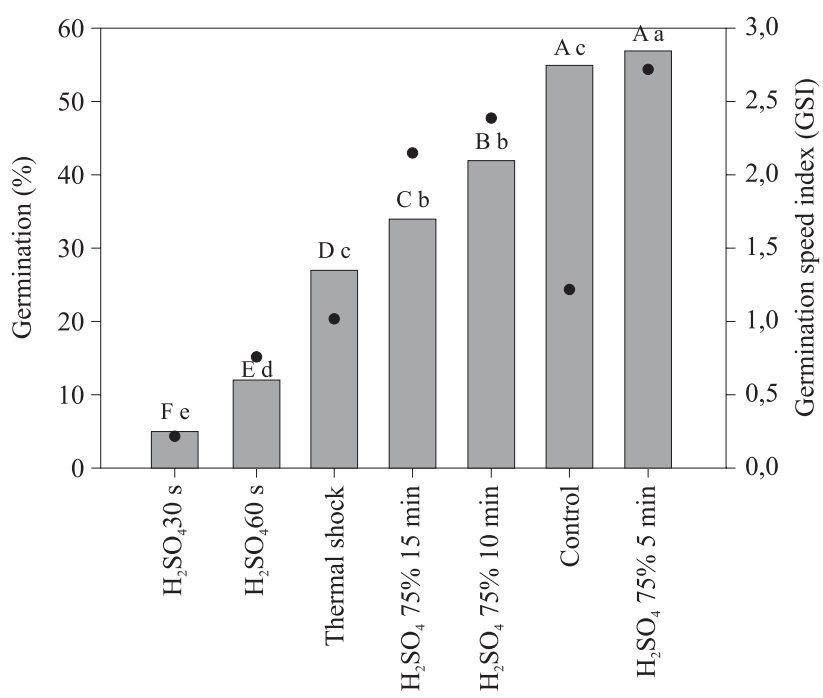

Figure 8. Germination behaviour of Miconia ligustroides diaspores subjected to different treatements aiming exogenous dormancy overcoming. Upper case letters compare \% germination (bars) and lower case compare GSI (dot).
To overcome the complex dormancy presented in $M$. ligustroides diaspores, they must be treated with $\mathrm{H}_{2} \mathrm{SO}_{4}$ $75 \%$ for 5 minutes and $400 \mathrm{mg} \mathrm{L}^{-1}$ of $\mathrm{GA}_{3}$ for 12 hours. The germination test must be done on Germtest ${ }^{\circledR}$ paper at $25^{\circ} \mathrm{C}$.

\section{References}

ALBUQUERQUE, K.S., GUIMARÃES, R.M., DE ALMEIDA, I.F. \& CLEMENTE, A.DA.C.S. 2007. Métodos para a superação da dormência em sementes de sucupira-preta (Bowdichia virgilioides Kunth.). Ciência e Agrotecnologia 31:1716-1721.

ALVES, E. 2004. Introdução à microscopia eletrônica de varredura. Universidade Federal de Lavras/FAEPE, Lavras.

ALVES, M.C.S. 2000. Superação de dormência em sementes de Bauhinia monandra Britt. e Bauhinia ungulata L.- Cesalpinoideae. Revista Brasileira de Sementes 22:139-144. 
AMARAL, L.V.I. \& PAULILO, M.T.S. 1992. Efeito da luz, temperatura, reguladores de crescimento e nitrato de potássio na germinação de Miconia cinnamomifolia (D.C.) Naudin. Ínsula 21:59-86.

ARTECA, R.N. 1996. Plant growth substances: principles and applications. Chapman and Hall, New York.

AZANIA, C.A.M., MARQUES, R.P., AZANIA, A.A.P.M. \& ROLIM, J.C. 2009. Superação da dormência de sementes de corda-de-viola (Ipomoea quamoclit e $I$. hederifolia). Planta Daninha 27:23-27.

BENEDITO, C.P., RIBEIRO, M.C.C., DE OLIVEIRA, M.K.T., GUIMARÃES, I.P. \& RODRIGUES, G.S.DE. O. 2009. Influência da cor e métodos de superação de dormência em sementes de albizia. Caatinga 22:121124.

BEWLEY, J.D. \& BLACK, M. 1994. Seeds: physiology of development and germination. Plenum Press, New York.

BONNET, A. \& DE QUEIROZ, M.H. 2006. Estratificação vertical de bromélias epifíticas em diferentes estádios sucessionais da Floresta Ombrófila Densa, Ilha de Santa Catarina, Santa Catarina, Brasil. Revista Brasileira de Botânica 29:217-228.

BRASIL. 2009. Ministério da Agricultura, Pecuária e Abastecimento. Regras para análise de sementes. Ministério da Agricultura, Pecuária e Abastecimento. Secretaria de Defesa Agropecuária. Brasília, DF: Mapa/ ACS.

CARDOSO, V.J.M. 2004. Dormência: estabelecimento do processo. In Germinação: do básico ao aplicado (A.G. Ferreira \& F. Borghetti, eds.). Artmed, Porto Alegre, p.95-108.

CARREIRA, R.C. \& ZAIDAN, L.B.P. 2007. Germinação de sementes de espécies de Melastomataceae de Cerrado sob condições controladas de luz e temperatura. Hoehnea 34:261-269.

CUNHA, W.R., SILVA, M.L.A., TURATTI, I.C.C., FERREIRA, D.S. \& BATARELLO, H.L. 2003. Avaliação da atividade analgésica de Miconia ligustroides (Melastomataceae) utilizando o teste de contorção abdominal em camundongos. Revista Brasileira de Farmacognosia 84:47-49.

CUNHA, W.R., CREVELIN, E.J., ARANTES, G.M., CROTTI, A.E.M., SILVA, M.L.A., FURTADO, N.A.J.C., ALBUQUERQUE, S. \& FERREIRA, D.S. 2006. A study of the tripanocidal activity of triterpene acids isolated from Miconia species. Phytotherapy Research 20:474-478.

FERREIRA, D.F. 1999. SISVAR: um programa para análises e ensino de estatística. Versão 4.3. Universidade Federal de Lavras, Lavras.

GODOI, S. \& TAKAKI, M. 2007. Seed germination in Miconia theaezans (Bonpl.) Cogniaux (Melastomataceae). Brazilian Archives of Biology and Technology 50:15168913.
GOLDENBERG, R. 2004. O gênero Miconia (Melastomataceae) no Estado do Paraná. Acta Botanica Brasílica 18:927-947.

LEYMARIE, J., ROBAYO-ROMERO, M.E., GENDREAU, E., BENECH-ARNOLD, R.L. \& CORBINEAU, F. 2008. Involvement of ABA in induction of secondary dormancy in barley (Hordeum vulgare L.) seeds. Plant and Cell Physiology 49:1830-1838.

MAGUIRE, J.D. 1962. Speed of germination-aid in selection and evaluation for seedling emergence and vigour. Crop Science 2:176-177.

MARTINS, A.B., SEMIR, J., GOLDENBERG, R. \& MARTINS, E. 1996. O gênero Miconia Ruiz \& Pav. no Estado de São Paulo. Acta Botanica Brasilica 10:267316.

MAYER, A.M. \& POLJAKOFF-MAYBER, A. 1989. The germination of seeds. McMillan, New York.

MCIVOR, J.G. \& HOWDEN, S.M. 2000. Dormancy and germination characteristics of herbaceous species in the seasonally dry tropics of northern Australia. Austral Ecology 25:214-222.

MELO, J.T., SILVA, J.A., TORRES, R.A.A., SILVEIRA, C.E.S. \& CALDAS, L.S. 1998. Coleta, propagação e desenvolvimento inicial de espécies do cerrado. In Cerrado: ambiente e flora (S.M. Sano, S.P. \& Almeida, eds.), Embrapa, Brasília, p.195-246.

NONOGAKI, H. 2006. Seed germination - the biochemical and molecular mechanisms. Breeding Science, Tokyo 56:93-105.

PENFIELD, S. 2008. Temperature perception and signal transduction in plants. New Phytologist 179:615-628.

POPINIGIS, F. 1977. Fisiologia da semente. Agiplan, Brasília.

SANTOS, D.L., SUGAHARA, V.Y. \& TAKAKI, M. 2005. Efeitos da luz e da temperatura na germinação de sementes de Tabebuia serratifolia (Vahl) Nich, Tabebuia chrysotricha (Mart. ex DC.) Standl. e Tabebuia roseo-alba (Ridl) Sand - Bignoniaceae. Ciência Florestal 15:87-92.

SEO, M., NAMBARA, E., CHOI, G. \& YAMAGUCHI, S. 2009. Interaction of light and hormone signals in germinating seeds. Plant Molecular Biology 69:463-472.

SIMON, E.W., MINCHIN, A., MCMENAMIN, M.M. \& SMITH, J.M. 1976. The low temperature limit for seed germination. New Phytologist 77:301-311.

THOMPSON, P.A. 1970. Characterization of the germination response to temperature of species and ecotypes. Nature 225:827-831.

TOH, S., IMAMURA,A., WATANABE,A., NAKABAYASHI, K., OKAMOT, M., JIKUMARU, Y., HANADA, A., ASO, Y., ISHIYAMA, K., TAMURA, N., IUCHI, S., KOBAYASHI, M., YAMAGUCHI, S., KAMIYA, Y., NAMBARA, E. \& KAWAKAMI, N. 2008. High temperature-induced abscisic acid biosynthesis and its role in the inhibition of gibberellin action in Arabidopsis seeds. Plant Physiology 146:1368-1385. 
TOWSEND, C.E. \& MCGINNIES, W.J. 1972. Mechanical scarification of cicer milkvetch (Astragalus cicer L.) seed. Crop Science 12:392-394.

VÁLIO, I.F.M. \& SCARPA, F.M. 2001. Germination of seeds of tropical pionner species under controlled and natural conditions. Revista Brasileira de Botânica 24: 79-84.

YAMAGUCHI, S. 2008. Gibberellin metabolism and its regulation. Annual Review of Plant Physiology and Plant Molecular Biology 59:225-251.
ZAIA, J.E. \& TAKAKI, M. 1998. Estudo da germinação de sementes de espécies arbóreas pioneiras: Tibouchina pulchra Cogn. e Tibouchina granulosa Cogn. Acta Botanica Brasilica 12:227-238.

ZAIDAN, L.B.P. \& BARBEDO, C.J. 2004. Quebra de dormência em sementes. In Germinação: do básico ao aplicado (A.G. Ferreira \& F. Borghetti, eds.). Artmed, Porto Alegre, p.134-146.

ZAIDAN, L.B.P. \& CARREIRA, R.C. 2008. Seed germination in Cerrado species. Brazilian Journal of Plant Physiology 20:167-181. 
